\title{
Renal hypoplasia, unilateral
}

INSERM

\section{Source}

INSERM. (1999). Orphanet: an online rare disease and orphan drug data base. Renal hypoplasia, unilateral. ORPHA:97361

Unilateral renal hypoplasia is a form of renal hypoplasia (see this term), a renal developmental anomaly in which one kidney is small and has a deficit in the number of nephrons present. 